\title{
THE IMPLEMENTATION OF COOPERATIVE LEARNING TYPE TEAMS GAME TOURNAMENT (TGT) METHOD TO IMPROVE STUDENTS MOTIVATION IN LEARNING ENGLISH
}

\author{
Ira Setia Pransiska ${ }^{1}$ \\ ${ }^{1}$ IKIP Siliwangi \\ ${ }^{1}$ irasetiapransiska@ student.ikipsiliwangi.ac.id
}

\begin{abstract}
The objective of this research is to describe the implementation of teams game tournament in learning English at SMP Pasundan 1 Cimahi. The research using descriptive qualitative method, and took 33 samples from seventh grade students. The writer collected data by interviewing and spreading questionnaires asked the students motivation which have 10 items adopted from Muhlisin, (2018). Percentage and descriptive explanations are applied in data processing. Based on this study, the writer found that; 1 . The students became more active in learning activities, 2 . The student's teamwork and courage were increasing while discussing group time, and 3 . The materials were easier to be accepted and understood by students. Those results indicated that the implementation of this method has enhanced the interest of students in learning English. From the questionnaires and interviews most of the students choose to agree statements too. So, it showed us that the implementation of cooperative learning type teams game tournament method was successfully improving student's motivation in learning English.
\end{abstract}

Keywords: Cooperative Learning, Teams Game Tournament, Students Motivation

\section{INTRODUCTION}

Today English considered important, because it not only a foreign language but become a global language. So it makes us have to be mastered English, especially for students who pursuing education. Indonesia has been implementing English ability as graduation standard. It started from elementary level to any college degree. This matter certainly worthwhile considering the significance of having the ability to understand English well. However, if we go back to see the learning process, it is hard to learn a new language that we have not understood before. Its difficulty reduces the student's motivation in learning English. Purnama et al., (2019) states motivation is the key to success in learning process. That means build student's motivation in learning English is an important thing, because motivation facilitating the process of delivering and receiving materials. As Kaswan \& Suprijadi (2014) states about the importance of activating learner's motivation: "The truth of the matter is that 99 percent of teaching is making the students feel interested in the material" cited in Rosmayanti \& Yanuarti, (2019). It becomes a challenge for teachers to find the types of active and fun learning methods in purpose to make their students be more motivated in learning proces. With the right method, English skills of students will improve better.

In this research conducted by the writer at SMP 1 Pasundan Cimahi, the writer found that student motivation in learning English were in the low degree. It can be analyzed from the lack of student's enthusiasm in learning process due to difficulties in understanding English. Based on these conditions, the writer conducted research by implementing one of the active learning 
methods called cooperative learning type teams game tournament to improve students motivation in learning English.

\section{Cooperative Learning}

There are several methods that can be applied in teaching and learning process, one of them is cooperative learning. Melian \& Solihat, (2019) states cooperative learning is a term of a set of general learning that was designed to enhance cooperation between students in learning. According to Slavin, 2011 cited in Tran, (2019) Cooperative learning is method of teaching where the students will be able to support each other to comprehend the lessons in several small groups. Meanwhile, Cruickshank, 1990 cited in Faricha \& Huda, (2019) state cooperative learning is a term that describes teaching procedures in which students collaborate in small groups and are given awards for high achieving students. From the explanations, cooperative learning is a learning method that put students into several small groups to build students closeness by cooperating, supportive atmosphere, and reach comprehensive lessons.

There are 5 components in cooperative learning pursuant to cooperative learning developers (Johnson \& Johnson, Siegel 2005) cited in Ahmad \& Mahmood, (2019); first is positive independence; develop feelings among team members who sink or swim together, second is individual accountability; makes each member accountable for their learning, third is face to face interaction; team members are made to express their thoughts aloud and discuss target content with each other, next is social skills; ensure that students follow group norms, take turns. Respect the view of others, and avoid conflicts, and the last is group processing; ensuring each team of member is on a path that shows the behavior of the task.

Since cooperative learning brings an active and fun learning process, so it fosters student's motivation to learn. Faricha \& Huda, (2019) states cooperative learning can increase student's enthusiasm for learning to get academic achievement. In addition, cooperative learning also encourages students to learn together and be responsible for all group members understanding. Kharisma \& Hidayati, (2018) concluded that cooperative learning is a good method for students to learn English easily.

Cooperative learning has several variations of method that could be applied in learning, including; Students Teams Achievement Divisions (STAD), Teams Game Tournament (TGT), Teams Accelerated Instruction (TAI), Jigsaw, and Cooperative Integrated Reading and Composition (CIRC), Cruickshank, 1990 cited in Faricha \& Huda, (2019). In this study, the writer has determined to implement cooperative learning using Teams Game Tournament (TGT) type for the research.

\section{Teams Game Tournament (TGT)}

According to Webb, 1989 cited in Rahmawati, (2017) the teams game tournament method is one method that can change the atmosphere for the better based on relevant theories and adapted to developments in society, as well as contributing to the principle that education must be centered on students. It means teams game tournament can encourage student's motivation to reach a good learning achievements together through their involvement in teamwork.

Cited in Faricha \& Huda, (2019), Academic principles that used in the teams game tournament, follows: 
1. Class presentations (Slavin, 1983), often direct instruction or lecture-discussion conducted by the teacher.

2. The team (Slavin Robert, 1995), the team consists of 4 or 5 students who represent a cross section of the class in terms of academic performance, gender, and ethnicity, main function of the team is to ensure that all members learn, and, overall specifically, prepare members to do the quiz correctly. Most often, this research involves students discussing joint problems, comparing answers, and correcting misunderstandings if teammates make mistakes.

3. Games (Slavin Robert, 1995), games consist of questions relevant to content designed to test the knowledge students get from class presentations and team exercises. The game is played on a table consisting of three students, each representing a different team. Most games are only numbered questions on the sheet. Students give numbered cards and try to answer questions that correspond to the number. Challenging rules allow players to challenge each other's answers.

4. Tournaments (Robert Slavin, 1995), a tournament is a structure in which a match takes place. Usually held on weekends or one unit after the teacher makes a class presentation and the team has time to practice with their worksheets. Thus, the team has the right preparation to participate in the tournament.

5. Team Recognition (Slavin Robert, 1995), team scores are calculated based on increasing team member scores, and individual certificates, class bulletins or broad bulletins recognize team high scores.

\section{METHOD}

For this study the writer used descriptive qualitative as the method. Descriptive qualitative is a kind of research method that uses techniques of search, classification and analysis the natural phenomena, Purnama et al., (2019). Shaleh, (2011) state that population is a bunch of people or objects whose conditions are going to be discovered through the research, cited in Verawati \& Kuswandi, (2020). The population of this research were the one class of students on seventh grade junior high school at Pasundan 1 Cimahi, they were 33 students. To collect the data, the writer using questionnaire and interview as instruments. The questionnaire adopted from Muhlisin, (2018). There are 10 items of statement translated into Bahasa to make the students easier while answering the statements. They have to choose one between agree or disagree. For interview, the writer took two students representatives as respondent of the class. It also orally translated into Bahasa indonesia to make the students easier to understand the questions and more confident to answer.

\section{RESULTS AND DISCUSSION}

\section{Results}

\section{A. Quesionnaire}

The questionnaire sheets distributed to 30 of 33 students in the class, 3 students were absent because 2 of them were sick and another one was permitted. This table show us the result of the questionnaire:

Table 1. Percentage (\%) of the result from the questionnaire of student's motivation in learning English using cooperative learning type teams game tournament method.

\begin{tabular}{llc}
\hline \multirow{2}{*}{ No } & \multicolumn{2}{c}{ Answer Choices } \\
\cline { 2 - 3 } & Statements & Agree Disagree \\
\hline
\end{tabular}




\begin{tabular}{|c|c|c|c|}
\hline 1 & $\begin{array}{l}\text { Through learning methods that have been applied, making me have a } \\
\text { high desire to take English lessons. }\end{array}$ & $(100 \%)$ & $(0 \%)$ \\
\hline 2 & $\begin{array}{l}\text { The learning method that has been applied can eliminate the fear of } \\
\text { being wrong in myself. }\end{array}$ & $(50 \%)$ & $(50 \%)$ \\
\hline 3 & $\begin{array}{l}\text { The learning that has been applied gives a special impression or } \\
\text { meaning to me. }\end{array}$ & $(86.7 \%)$ & $(13.4 \%)$ \\
\hline 4 & $\begin{array}{l}\text { This learning method makes it easy for me to understand the subject } \\
\text { matter being taught. }\end{array}$ & $(93.4 \%)$ & $(6.7 \%)$ \\
\hline 5 & The learning process is interesting and fun. & $(100 \%)$ & $(0 \%)$ \\
\hline 6 & $\begin{array}{l}\text { I feel that the time needed to master the concept of learning is } \\
\text { shorter. }\end{array}$ & $(46.7 \%)$ & $(53.4 \%)$ \\
\hline 7 & I am motivated to get good achievements. & $(93.4 \%)$ & $(6.7 \%)$ \\
\hline 8 & The learning process can improve my critical thinking skills. & $(93.4 \%)$ & $(6.7 \%)$ \\
\hline 9 & $\begin{array}{l}\text { I feel to be more valued when expressing opinions during the } \\
\text { learning process. }\end{array}$ & $(66.7 \%)$ & $(33.4 \%)$ \\
\hline 10 & $\begin{array}{l}\text { I became more courageous in expressing my opinion during the } \\
\text { learning process. }\end{array}$ & $(60 \%)$ & $(40 \%)$ \\
\hline
\end{tabular}

\section{B. Interview}

On this data collecting by interview, the writer asked respondents about their motivation in learning. From the interview respondents issued several statements related to the learning methods that have been implementing and the effects on their motivation in learning, they argue that 1 . They feel Teams Game Tournament (TGT) method brings them became more active in learning activities, 2. They feel the teamwork and courage were increasing by using this method, because it built their closeness and felt more fun while they can help each other, and 3. They think that the materials were easier to be accepted and understood by using this method.

\section{Discussion}

From the data of questionnaire, the writer concluded that the most students have motivation to learn English after implemented cooperative learning, teams game tournament method type for their study. It proved by the percentage of agree to the statements higher than percentage of disagree. Furthermore, from the calculation of answered questionnaire indicated that the 30 students of seventh grade junior high school at Pasundan 1 Cimahi has higher motivation to learn English using this method.

From the interview, the writer took two students representatives as respondent of the class. This interview was also orally translated into Bahasa Indonesia to make the students easier to understand the questions and make them more confident to answer. The respondents are the students who have finished their questionnaire. The writer provided them an empty seat in front of the teacher's desk, so the writer can chatting privately while waiting for the other students to finish the questionnaire sheets.

Respondent also said that previously some students often found it difficult to learn English because of their limitations in understanding vocabulary, and they felt embarrassed to ask the teacher. In the class, they were attended but did not understand the materials. They just sat lazily 
listening to the teachers' explanation without understanding and accepting the materials. As a result, when they had assignments they always confused and had no idea about what they have to do. But after implementing this method, they didn't really feel those things anymore because they can build mutual cooperation with group friends, express their opinions, help each other with difficulties, and also felt more fun. These things will build their motivation to learn, because the classroom atmosphere is not rigid. The outcome of interview, the writer concluded that respondents were motivated in learning process. It is means that the implementation of cooperative learning type teams game tournament method to improve student's motivation in learning English was successful.

From the presentation of the data above through questionnaire and interviews, most of the students answered agree to the questions that given to them and gave some positive statements in the interview season. These results give us an explanation which shows that most students have high motivation in learning English using cooperative learning type team's game tournament method.

Motivation is one of the important things which effect student's attitude and achievement. In the finding of this study, the students more active, and they have a good motivation in learning. So this condition can be useful for teacher to make students succeed in understanding English better.

\section{CONCLUSION}

Motivation is an important factor that influences learning activities. Learning objectives will be hard to achieve without motivation, because the efforts and desires of students are very influential on achievement of learning objectives. Therefore, by getting motivated the students will be excited in the process of learning, so they will be encouraged to understand English as well.

In the finding of this study, cooperative learning type teams game tournament method can advance student's motivation in seventh grade at Pasundan 1 Ciamhi middle school. This research has proven that active and fun learning activities can build better learning motivation; it also supported by group activities on cooperative learning that facilitating students to express themselves, cooperate with each other, build closeness between friends, and they were able to create a non-rigid classroom atmosphere. This cooperative learning can be a more useful teaching method to increase student's motivation and better learning outcomes. Thus, cooperative learning is highly proposed as a more effective pedagogical teaching method in demanding educational innovation in Indonesia.

\section{ACKNOWLEDGMENTS}

Praise to Allah who has given us knowledge, healthy and opportunity. The accomplishment of this research article is made possibly because of Allah's help and mercy. The writers would like to say thank you to IKIP Siliwangi which give us opportunity to publish this article and also to the writer's article supervisors who always provide support to the writers when conducting this study.

\section{REFERENCES}

Ahmad, Z., \& Mahmood, N. (2019). Effects of Cooperative Learning Models on Prospective 
Teachers' Achievement and Equity. Pakistan Journal of Education, 36(2), 43-62.

Faricha, Z., \& Huda, K. (2019). the Effectiveness of Using Teams Games Tournaments ( Tgt ) in Teaching Reading of Narrative Text the Effectiveness of Using Teams Games Tournaments in Teaching Reading of Narrative Text. Journal of English Education and Technology, 01(01), 20-34.

Kharisma, I., \& Hidayati, L. A. (2018). Students' Perception in Learning English Using Cooperative Learning Activity. PROJECT (Professional Journal of English Education), 1(3), 207. https://doi.org/10.22460/project.v1i3.p207-216

Melian, O. H., \& Solihat, M. R. (2019). Analyzing Students' Speaking Activities in Teaching Learning Process Using Stad Method. 2(3), 256-261.

Muhlisin, A. (2018). Analysis of students'response of the implementation of rms (reading, mind mapping, and sharing) learning model in philosophy of science. Unnes Science Education Journal, 7(1), 13-18.

Purnama, N. A., Rahayu, N. S., \& Yugafiati, R. (2019). Students' Motivation in Learning English. PROJECT (Professional Journal of English Education), 2(4), 539. https://doi.org/10.22460/project.v2i4.p539-544

Rahmawati. (2017). Improving English Speaking Ability. English Education Journal, 8(1), 113.

Rosmayanti, D., \& Yanuarti, H. (2019). The Relationship Between Students' Motivation and Their Learning Achievement. Professional Journal of English Education, 1(6), 783-788.

Tran, V. D. (2019). Does cooperative learning increase students' motivation in learning? International Journal of Higher Education, 8(5), 12-20. https://doi.org/10.5430/ijhe.v8n5p12

Verawati, V., \& Kuswandi, W. (2020). Comparison Between Cooperative Learning Methods and Problem Based Learning Using Personal Letter in Teaching Students' Ability in Writing At Sma Sebelas Maret Bandung. PROJECT (Professional Journal of English Education), 3(2), 290-298. https://doi.org/10.22460/project.v3i2.p290-298 